\title{
SISTEM INFORMASI KAS MASUK DAN KAS KELUAR BERBASIS WEB PADA PT RAKHA REKANANTA PONTIANAK
}

\author{
Nurmalasari ${ }^{1}$, Anna $^{2}$, Fariatul $\mathrm{Ilmi}^{3}$ \\ 1,2,3 Universitas Bina Sarana Infromatika \\ e-mail: 1nurmalasai.nnr@bsi.ac.id, 2anna.nnz@bsi.ac.id, ${ }^{4}$ fariatulilmi03@gmail.com
}

\begin{abstract}
ABSTRAK
PT. Rakha Rekananta merupakan perusahaan jasa yang bergerak di bidang kontraktor. Setiap kegiatan transaksi kas masuk dan kas keluar di catat kedalam nota kemudian disalin ke MS. Excel. Hal ini berakibat buruk seperti keterlambatan, kesalahan perhitungan dari pelaku pengolahan data dan hasil laporan yang tidak akurat di karenakan sumber data yang memakan waktu yang relatif lama di karenakan jumlah data yang diolah banyak. Maka dari itu penelitian ini membahas tentang pembuatan sistem informasi kas masuk dan kas keluar menggunakan model air terjun sebagai metode pengembangan perangkat lunak yang terdiri dari analisa, desain, pembuatan kode program dan pengujian. Teknik pengumpulan data yang digunakan terdiri dari observasi, wawancara dan studi pustaka. Sistem yang dibuat ini terdiri dari dua (2) level akses yaitu admin dan direktur. Admin dapat melakukan mengelola data akun, mengolah kas masuk dan kas keluar, mengelola laporan jurnal umum, buku besar, arus kas, laba rugi. Direktur dapat mengelola data pengguna atau user login dan dapat mengakses laporan jurnal umum, buku besar, arus kas, laba rugi. Sistem informasi kas masuk dan kas keluar ini diharapkan bisa membantu PT. Rakha Rekananta dalam pengolahan data yang berkaitan dengan kas masuk dan kas keluar
\end{abstract}

Kata Kunci: Sistem Informasi Akuntansi, Kas Masuk, Kas Keluar, Desktop

\begin{abstract}
PT. Rakha Rekananta is a service company engaged in contracting consultants. Every cash transaction and cash out transaction activity is recorded in a memorandum then copied to MS. Excel. This has bad consequences such as delays, miscalculations from data processing actors and inaccurate report results due to data sources that take a relatively long time due to the large amount of data processed. Therefore, this Final Project discusses the making of information systems for cash in and cash out using the waterfall model as a software development method consisting of analysis, design, program code creation and testing. Data collection techniques used consisted of observation, interviews and literature study. This system consists of two (2) access levels, namely admin and director. Admins can manage account data, process cash in and cash out, manage general journal reports, ledgers, cash flow, profit and loss. Director can manage user data or user login and can access general journal reports, general ledger, cash flow, profit and loss. Cash inflow and cash out information system is expected to help PT. Rakha Rekananta in processing data related to cash in and cash out.
\end{abstract}

Keywords: Accounting Information System, Cash In, Cash out, Desktop

\section{Pendahuluan}

Seiring dengan kemajuan dan perkembangan teknologi, teknologi informasi dapat digunakan untuk mengolah data dalam dunia kerja maupun pendidikan agar mendapatkan informasi yang akurat dan berkualitas. Serta dimanfaatkan untuk mempermudah penyelesaian pekerjaaan. Dalam kas masuk dan kas keluar, peranan komputer dapat meningkatkan sistem operasional perusahaan sehingga memudahkan perusahaan dalam hal pengeluaran dan pemasukan serta laporan keuangan.

PT. Rakha Rekananta adalah perusahaan jasa yang bergerak dibidang konsultan kontraktor yang berada di kota Pontianak. PT. Rakha Rekananta telah 
menggunakan komputer sebagai alat bantu dalam pengolahan kas masuk dan kas keluar, namun hanya sebatas penggunaan aplikasi Microsoft Excel. Penggunaan Microsoft Excel tersebut belum secara maksimal memudahkan proses pengolahan data kas masuk dan kas keluar pada PT. Rakha Rekananta dikarenakan harus merekap satu persatu transaksi kas masuk dan kas keluar yang bersumber dari notanota untuk dijadikan laporan keuangan. Pengolahan data seperti ini memerlukan tenaga dan waktu yang relatif lama, kesalahan pada saat pengisian data yang berpengaruh pada kualitas dari informasi atau keakuratan dalam laporan keuangan.

\subsection{Pengertian Sistem}

Menurut (Jayanti \& Iriani, 2014) menjelaskan bahwa "Sistem adalah sebuah tatanan yang terdiri atas sejumlah komponen fungsional yang saling berhubungan dan secara bersama-sama bertujuan untuk memenuhi suatu proses atau pekerjaan tertentu".

Sistem adalah suatu jaringan kerja dari prosedur-prosedur yang saling berhubungan, berkumpul bersama-sama untuk melaksanakan suatu kegiatan atau menyelesaikan sasaran tertentu. Pengertian sistem secara fisik adalah kumpulan elemen-elemen yang beroperasi bersamasama untuk menyelesaikan suatu sasaran tertentu (Assronjani et al., 2019).

Berdasarkan dua definisi diatas, dapat disimpulkan bahwa sistem adalah sebuah tatanan yang saling berhubungan untuk melakukan kegiatan atau menyelesaikan suatu sasaran tertentu.

\subsection{Sistem Informasi}

Menurut Fajarianto et al (2017) menyatakan bahwa "Sistem Informasi adalah suatu sistem didalam suatu organisasi yang mempertemukan kebutuhan pengolah transaksi harian yang mendukung fungsi operasi organisasi yang bersifat manajerial dengan kegiatan strategi dari suatu organisasi untuk dapat menyediakan kepada pihak luar tertentu dengan laporan-laporan yang diperlukan".

Menurut (Mara Destiningrum, 2017) mengemukakan bahwa "Sistem Informasi adalah suatu sistem didalam suatu organisasi yang mempertemukan kebutuhan pengolahan transaksi harian, mendukung operasi, bersifat manjerial dan kegiatan strategi dari suatu organisasi dan menyediakan pihak luar tertentu dengan laporan-laporan yang diperlukan".

\subsection{Kas}

Menurut (Putri et al., 2018) menjelaskan bahwa "Kas adalah aset keuangan yang digunakan untuk kegiatan operasional perusahaan. Kas merupakan aset yang paling likuid karena dapat digunakan untuk membayar kewajiban perusahaan".

Kas merupakan uang tunai dan alat pembayaran lainnya yang digunakan untuk membiayai operasi perusahaan. Kas harus siap tersedia untuk digunakan membiayai operasi dan membayar kewajiban lancar perusahaan dan harus bebas dari setiap ikatan konseptual yang membatasi penggunaannya (Abdullah \& Siswanti, 2019).

\subsection{Kas Masuk}

Kas Masuk (cash inflows) merupakan penerimaan kas yang berasal dari kegiatan rutin perusahaan, misalnya penjualan tunai, penerimaan piutang maupun penerimaan kas yang bersifat tidak rutin misalnya penyertaan modal, penjualan saham, penjualan aktiva perusahaan (Taruna \& Kas, 2018).

Menurut (Jaya, 2018) menjelaskan bahwa "Penerimaan kas perusahaan berasal dari dua sumber utama, penerimaan kas dari penjualan tunai dan penerimaan kas dari piutang. Sumber penerimaan kas terbesar suatu perusahaan dagang berasal dari transaksi penjualan tunai".

\subsection{Kas Keluar}

Kas Keluar (cash out flows) adalah pengeluaran yang bersifat kontinyu, seperti pembayaran bunga, dividen dan pembayaran pajak. Arus kas berlangsung terus menerus selama perusahaan menjalankan kegiatannya (Taruna \& Kas, 2018).

Menurut (Suryati, 2018) mengemukakan bahwa "pengeluaran kas adalah suatu transaksi yang menimbulkan berkurangnya saldo kas dan bank milik perusahaan yang diakibatkan adanya pembelian tunai, pembayaran utang maupun transaksi yang menyebabkan berkurangnya kas". 


\section{Metode Penelitian}

Metode penelitian adalah cara maupun strategi yang dapat ditempuh untuk melakukan untuk melakukan suatu penelitian, dalam penelitian ini Penulis menggunakan metode penelitian deskriptif. Dan pada penulisan bagian ini, dijelaskan mengenai metode pengumpulan data dan metode pengembangan sofware yang digunakan dalam membuat aplikasi berbasis web pada kas masuk dan kas keluar.

Pengumpulan data merupakan kegiataan yang berkaitan dengan mengumpulkan data-data statistik dengan menggunakan beberapa metode pengumpulan data. Penelitian ini menggunakan tiga teknik metode pengumpulan data yaitu observasi, wawancara dan studi pustaka.

Penelitian ini juga menggunakan metode air terjun atau waterfall sebagai metode pengembangan software. Model SDLC air terjun (waterfall) sering juga disebut model sekuensial linier (sequential linear) sebagai pengumpulan data. Menurut Rossa dan Shalahuddin (2015:28) Model waterfall yaitu "model air terjun menyediakan pendekatan alur hidup perangkat lunak secara sekuensial atau terurut dimulai dari analisis, desain, pengkodean, pengujian, dan tahap pendukung (support)". Adapula tahap-tahap yang ada di dalam metode air terjun (waterfall) adalah Analisis kebutuhan perangkat lunak (software), desain, Code Generation, pengujian (Testing) dan pendukung (Support)

\section{Hasil dan Pembahasan \\ 3.1 Activity Diagram}

Diagram aktifitas atau activity diagram mengambarkan workflow (aliran kerja) atau aktivitas dari sebuah sistem atau proses bisnis atau menu yang ada pada perangkat lunak. Activity diagram mengambarkan aktivitas sistem bukan apa yang dilakukan aktor, jadi aktivitas yang dapat dilakukan oleh sistem. Berikut merupakan Activity Diagram yang terdapat pada PT. Rakha Rekananta Pontianak.

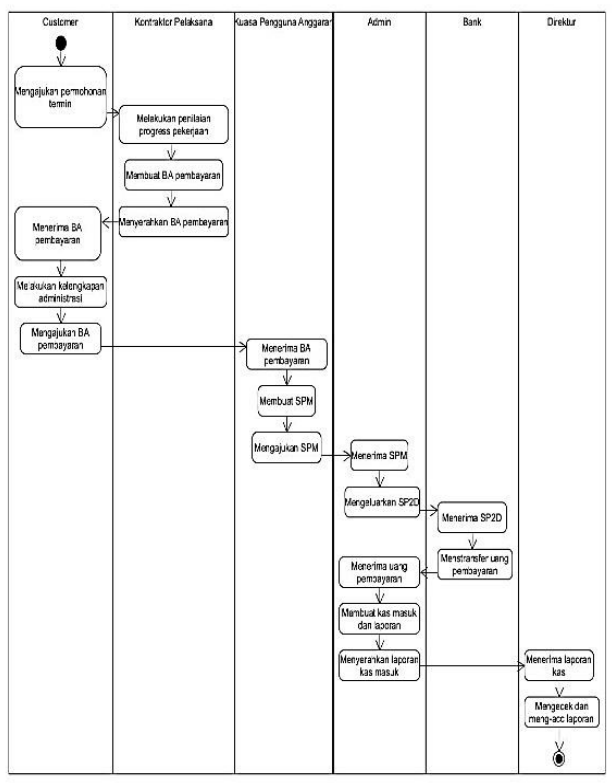

Sumber: PT. Rakha Rekananta (2019)

Gambar 1. Activity Diagram Kas Masuk PT. Rakha Rekananta Pontianak

Keterangan:

BA: Berita Acara

SPM: Surat Perintah Membayar

SP2D: Surat Perintah Pencairan Dana

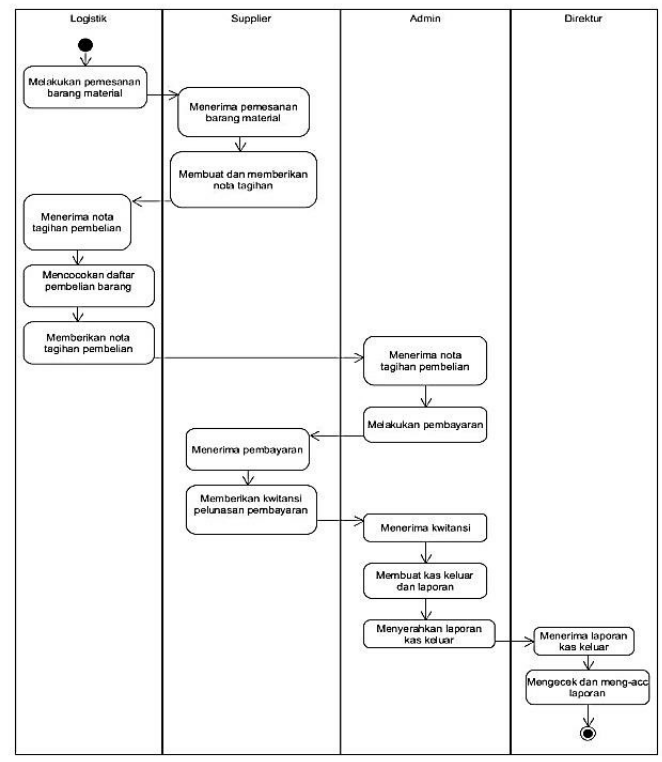

Sumber: PT. Rakha Rekananta (2019)

Gambar 2. Activity Diagram Kas Keluar

PT. Rakha Rekananta PontianakUse Case Diagram 
Kebutuhan pengguna yang telah diuraikan pada tahapaan analisa kebutuhan pengguna untuk sistem informasi kas masuk dan kas keluar pada PT. Rakha Rekananta Pontianak akan dimodelkan menjadi use case diagram sebagai berikut:

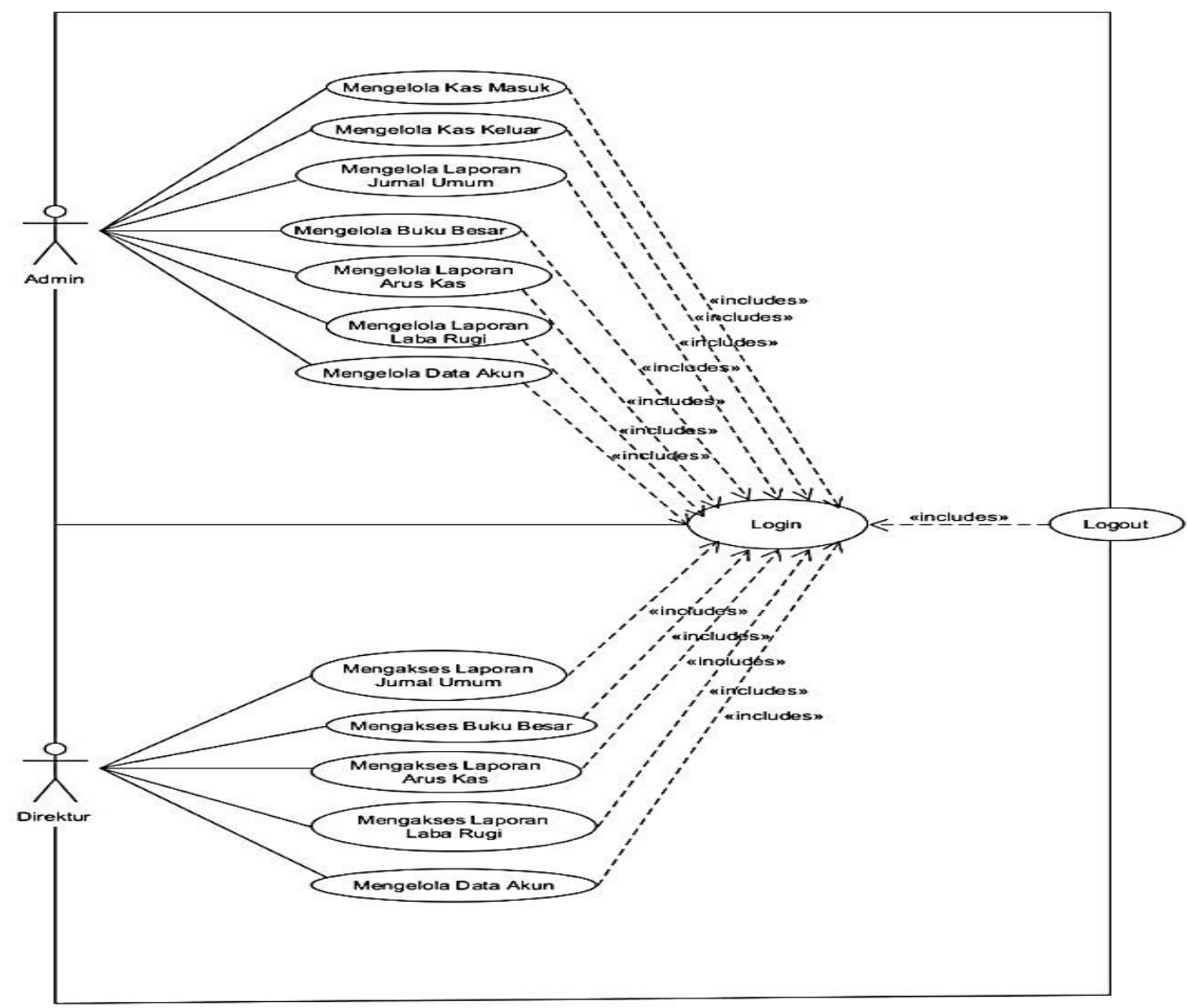

Sumber: Hasil penelitian (2019)

Gambar 3. Use Case Diagram Sistem Informasi Kas Masuk dan Kas Keluar PT. Rakha Rekananta Pontianak

Tabel 1.

Deskripsi Use Case Sistem Informasi Kas Masuk dan Kas Keluar Use Case Narative Sistem Informasi Kas Masuk dan Kas Keluar

\begin{tabular}{|l|l|}
\hline Tujuan & $\begin{array}{l}\text { Admin dan direktur dapat mengelola dan } \\
\text { mengakses data yang ada di dalam aplikasi } \\
\text { sistem informasi kas masuk dan kas keluar. }\end{array}$ \\
\hline Deskripsi & $\begin{array}{l}\text { Sistem ini memberikan fasilitas kepada } \\
\text { admin untuk mengelola data kas masuk, } \\
\text { data kas keluar, mengakses laporan jurnal } \\
\text { umum, buku besar, arus kas, laba rugi dan } \\
\text { mengelola data akun. Sistem ini juga } \\
\text { memberikan fasilitas kepada direktur untuk } \\
\text { mengakses laporan jurnal umum, buku } \\
\text { besar, arus kas, laba rugi dan mengelola } \\
\text { data pengguna atau user login. }\end{array}$ \\
\hline
\end{tabular}




\begin{tabular}{|c|c|}
\hline \multicolumn{2}{|l|}{ Skenario Utama } \\
\hline Aktor & Admin \& Direktur \\
\hline Kondisi Awal & $\begin{array}{l}\text { Admin \& Direktur harus melakukan login } \\
\text { dengan cara mengisi username dan } \\
\text { password. }\end{array}$ \\
\hline Aksi Aktor & Reaksi Sistem \\
\hline $\begin{array}{l}\text { 1. Admin atau Direktur memilih menu data } \\
\text { akun } \\
\text { 2. Admin memilih menu transaksi kas masuk } \\
\text { dan kas keluar } \\
\text { 3. Admin atau Direktur memilih menu laporan } \\
\text { jurnal umum } \\
\text { 4. Direktur memilih menu tambah pengguna } \\
\text { atau user } \\
\text { 5. Direktur atau Admin memilih menu laporan } \\
\text { buku besar } \\
\text { 6. Direktur atau Admin memilih menu laporan } \\
\text { 7. Direktur atau Admin memilih menu laporan } \\
\text { laba rugi }\end{array}$ & $\begin{array}{l}\text { Sistem menampilkan halaman data akun } \\
\text { Sistem menampilkan halaman transaksi } \\
\text { kas masuk dan kas keluar } \\
\text { Sistem menampilkan halaman laporan } \\
\text { jurnal umum } \\
\text { Sistem menampilkan halaman data tambah } \\
\text { pengguna atau user } \\
\text { Sistem menampilkan halaman laporan buku } \\
\text { besar } \\
\text { Sistem menampilkan halaman laporan arus } \\
\text { kas } \\
\text { Sistem menampilkan halaman laporan laba } \\
\text { rugi }\end{array}$ \\
\hline Kondisi Akhir & $\begin{array}{l}\text { Jika sesuai perintah maka sistem akan } \\
\text { menampilkan menu yang dipilih oleh } \\
\text { pengguna }\end{array}$ \\
\hline
\end{tabular}

Sumber: Hasil Penelitian (2019)

\subsection{Activity Diagram}

Activity diagram merupakan diagram yang menerangkan tentang aktifitasaktifitas yang dapat dilakukan oleh seorang entity atau pengguna yang akan diterapkan pada aplikasi. Setiap use case pada use case diagram ini akan dijelaskan proses bisnisnya menggunakan activity diagram. Activity diagram untuk setiap kegiatan dari sistem informasi kas masuk dan kas keluar pada PT. Rakha Rekananta Pontianak digambarkan pada halaman berikut.

1. Activity diagram login

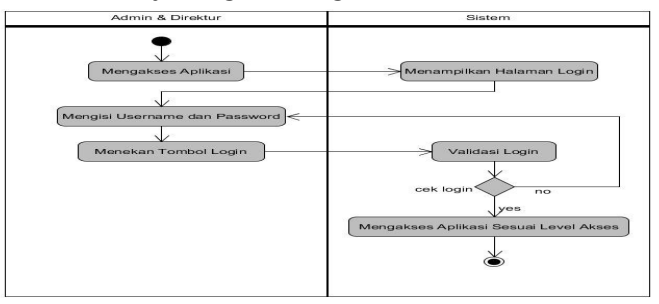

Sumber: Hasil Penelitian (2019)

Gambar 4. Activity Diagram Login
2. Activity diagram mengelola data akun

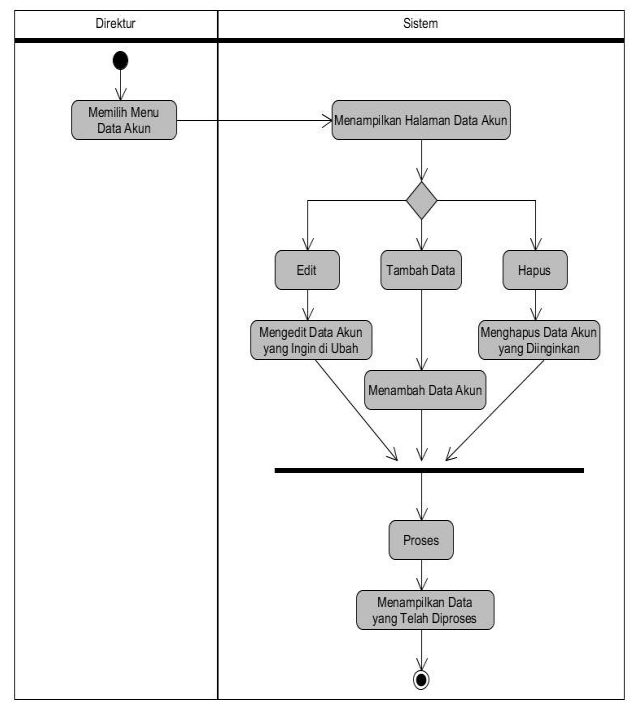

Sumber: Hasil Penelitian (2019)

Gambar 5. Activity Diagram Mengelola Data Akun 
3. Activity diagram mengelola data pengguna atau user login

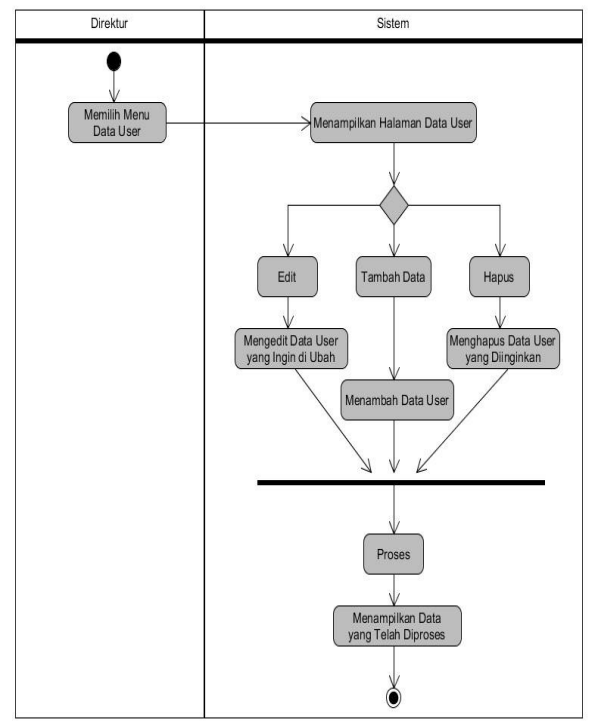

Sumber: Hasil Penelitian (2019)

Gambar 6. Activity Diagram Mengelola Data Pengguna atau User Login

4. Activity diagram mengelola data kas masuk

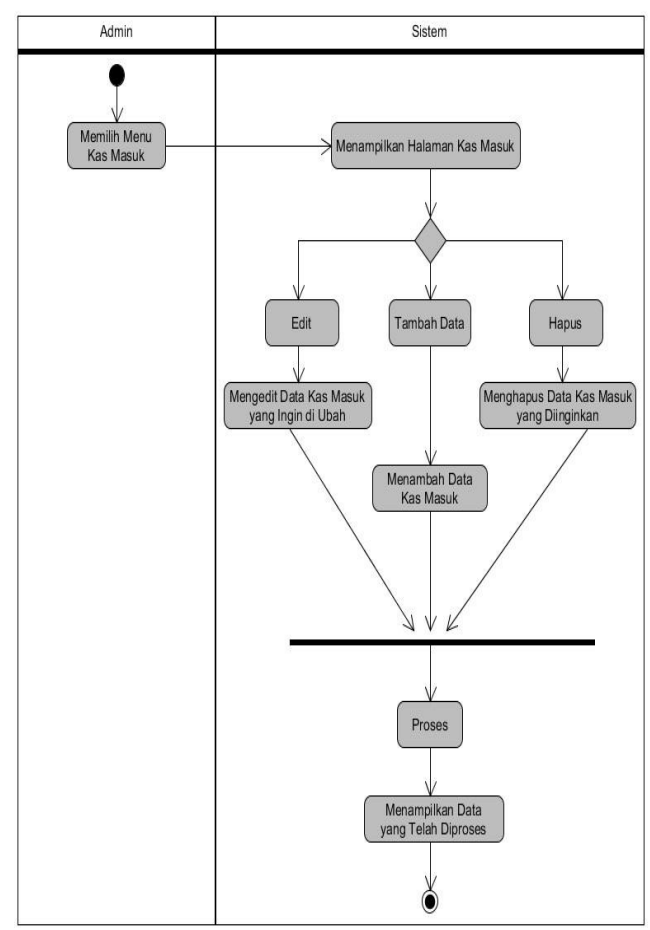

Sumber: Hasil Penelitian (2019)

Gambar 7. Activity Diagram Mengelola Data Kas Masuk
5. Activity diagram mengelola data kas keluar

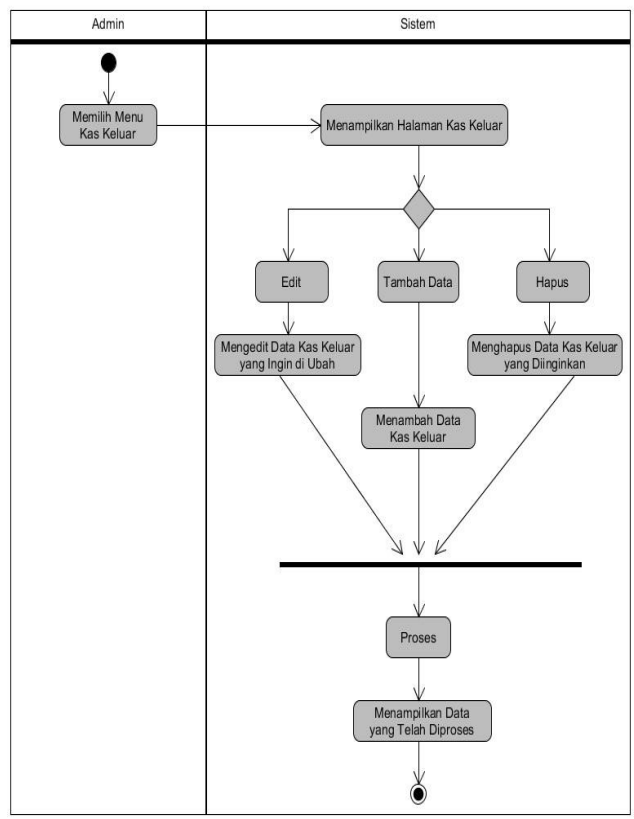

Sumber: Hasil Penelitian (2019)

Gambar 8. Activity Diagram Mengelola Data Kas Keluar

6. Activity diagram mengakses jurnal umum

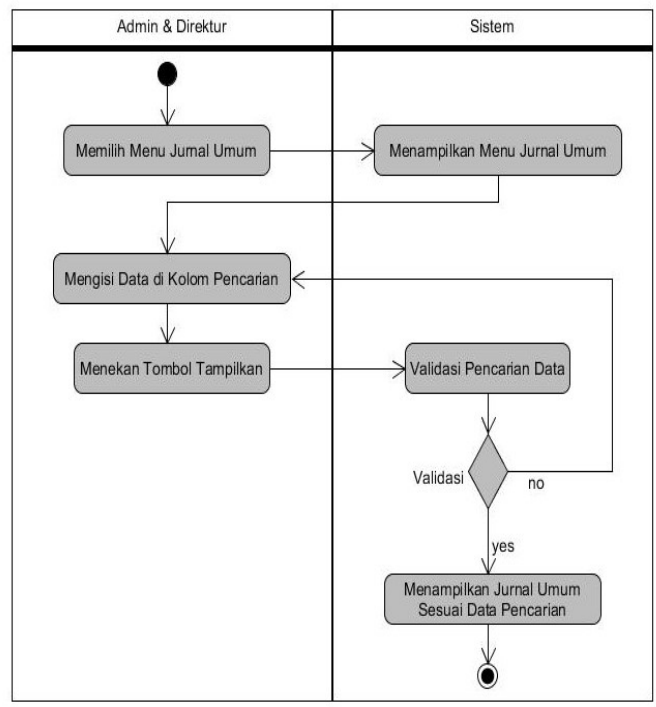

Sumber: Hasil Penelitian (2019)

Gambar 9. Activity Diagram Mengakses Jurnal Umum 
7. Activity diagram mengakses buku besar

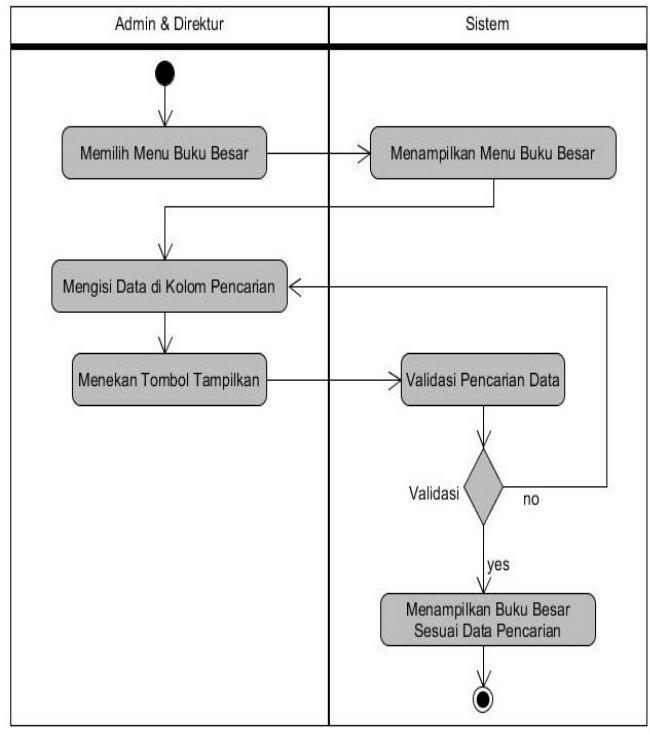

Sumber: Hasil Penelitian (2019)

Gambar 10. Activity Diagram Mengakses Buku Besar

8. Activity diagram mengakses arus kas

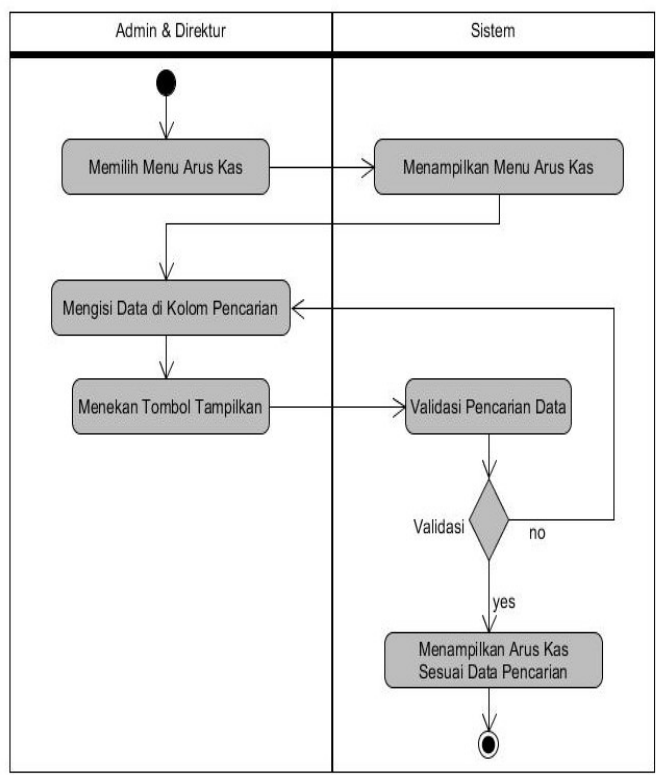

Sumber: Hasil Penelitian (2019)

Gambar 11. Activity Diagram Mengakses Arus Kas
9. Activity diagram mengakses laba rugi

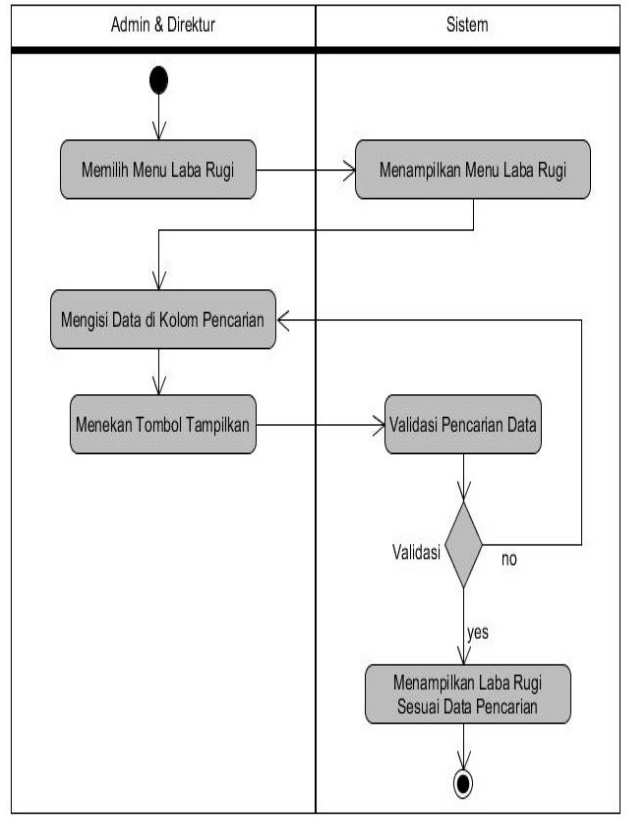

Sumber: Hasil Penelitian (2019)

Gambar 12. Activity Diagram Mengakses Laba Rugi

\section{Activity diagram logout}

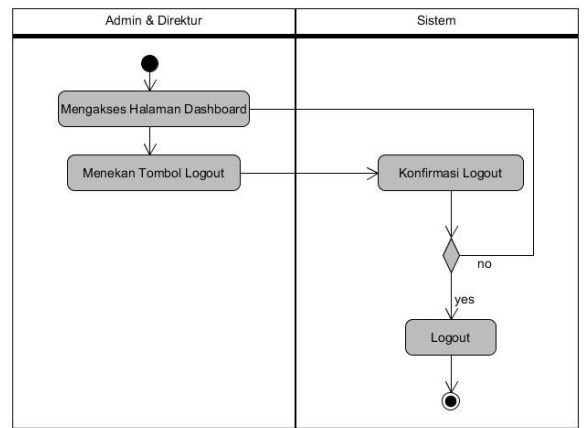

Sumber: Hasil Penelitian (2019)

Gambar 13. Activity Diagram Logout

\subsection{Desain}

Perancangan perangkat lunak atau desain dari sistem informasi kas masuk dan keluar pada PT. Rakha Rekananta Pontianak ini terdiri dari tahapan perancangan basis menggunakan Entity Relationship Diagram (ERD) dan Logical Record Structure (LRS) untuk memvisualisasikan rancangan basis data, setiap entitas pada rancangan basis data kemudian diuraikan menjadi spesifikasi file dan tampilan antar muka atau user interface yang telah dibuat. 


\subsection{Entity Relationship Diagram (ERD)}

ERD adalah sebuah pendekatan Topbottom dalam perancangan basis data yang dimulai dengan mengidentifikasikan data- data terpenting yang disebut entitas. (Adrifa et al., 2018). Berikut ini adalah bentuk dari Entity Relationship Diagram (ERD) yang dirancang.

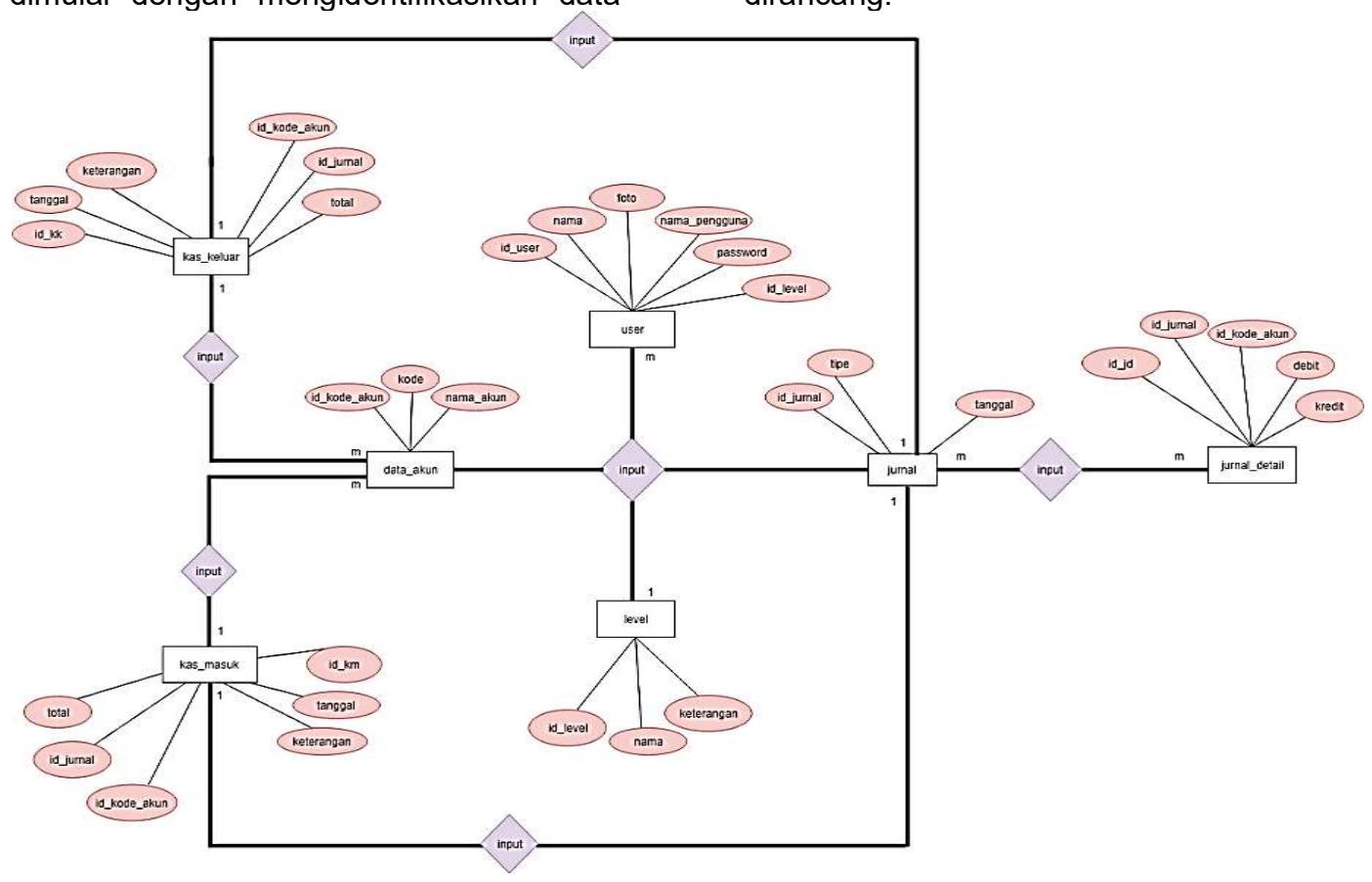

Sumber : Hasil Perancangan (2019)

Gambar 14. Rancangan Entity Relationship Diagram (ERD)

\subsection{Logical Record Structure (LRS)}

$$
\text { Menurut (Suryanto, 2016) }
$$

mengemukakan bahwa "LRS merupakan hasil dari Entity Relationship (ER) berserta atributnya sehingga bisa terlihat hubungan-
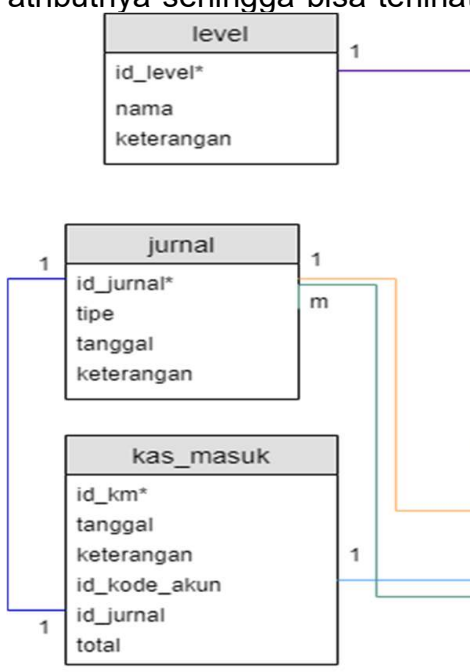

password

d_level

hubungan antara entitas". Adapun rancangan Logical Record Structure (LRS) untuk sistem informasi kas masuk dan kas keluar pada PT. Rakha Rekananta Pontianak sebagai berikut.

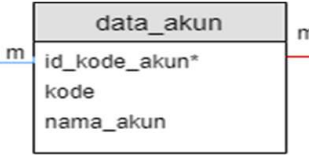

Sumber : Hasil Perancangan (2019)

Gambar III. 15. Rancangan Logical Record Structure (LRS) 


\subsection{User Interface}

Tampilan antar muka atau user interface dari sistem informasi kas masuk dan kas keluar pada PT. Rakha Rekananta Pontianak akan disajikan sesuai dengan level akses penggunanya, yaitu admin dan direktur.

\subsubsection{User Interface Bagian Admin}

Fasilitas yang didapat oleh admin dari sistem informasi kas masuk dan kas keluar pada PT. Rakha Rekananta Pontianak ini terdiri dari pengolahan data akun, mengakses laporan jurnal umum, mengakses laporan buku besar, mengakses laporan arus kas, mengakses laporan laba rugi. Berikut ini adalah hasil tampilan antar muka atau user interface yang disediakan untuk level pengguna admin.

1. User interface login admin

Pada halaman ini, admin harus mengisi username dan password untuk dapat mengakses aplikasi. Apabila berhasil maka admin dapat mengakses halaman menu utama atau dashboard.
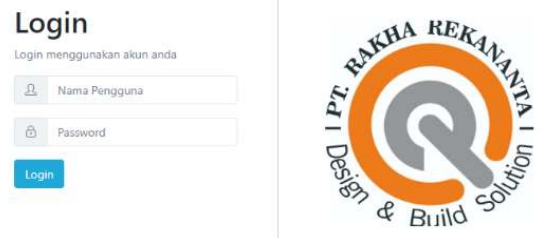

Sumber: Hasil Perancangan (2019)

\section{Gambar 16. User Interface Login Admin}

2. User interface dashboard admin Halaman dashboard admin ini dapat diakses apabila admin telah melewati proses login. Pada halaman dashboard admin ini menyediakan master data, data transaksi, mengelola laporan dan logout.
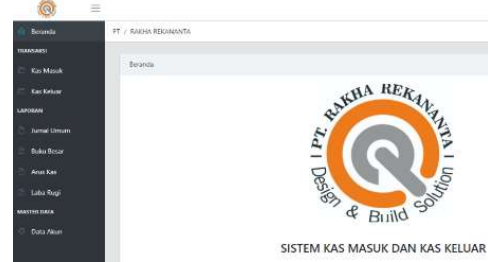

Sumber: Hasil Perancangan (2019)

Gambar 17. User Interface Dashboard Admin
3. User interface menu kas masuk

Tambah data pendapatan dapat diakses apabila admin menekan tombol tambah data. Admin dapat menambah data pendapatan atau kas masuk dengan cara mengisi kolom yang tersedia dan menekan tombol simpan.

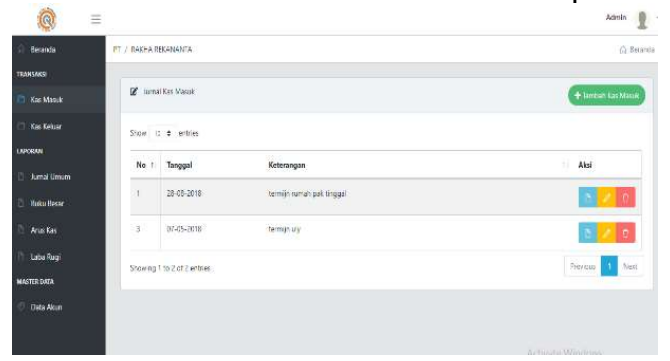

Sumber: Hasil Perancangan (2019)

Gambar 18. User Interface Menu Kas Masuk

4. User interface menu kas keluar

Pada halaman ini, admin dapat mengelola data pembayaran mulai dari penambahan, pengubahan dan penghapusan data pembayaran atau kas keluar.

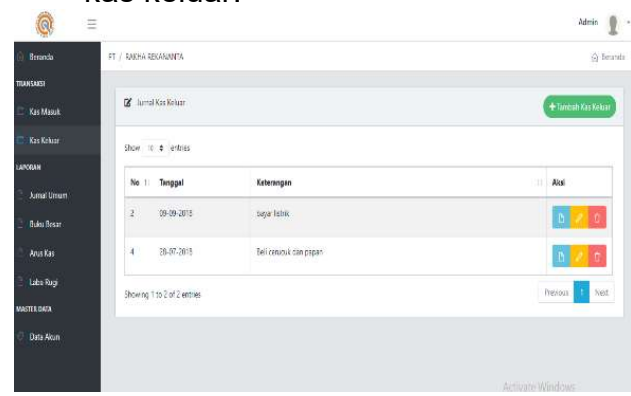

Sumber: Hasil Perancangan (2019)

Gambar 19. User Interface Menu Kas Keluar

5. User interface jurnal umum

Pada halaman laporan jurnal umum, admin dapat melihat atau mengakses laporan jurnal umum sesuai dengan periode tanggal, bulan dan tahun.

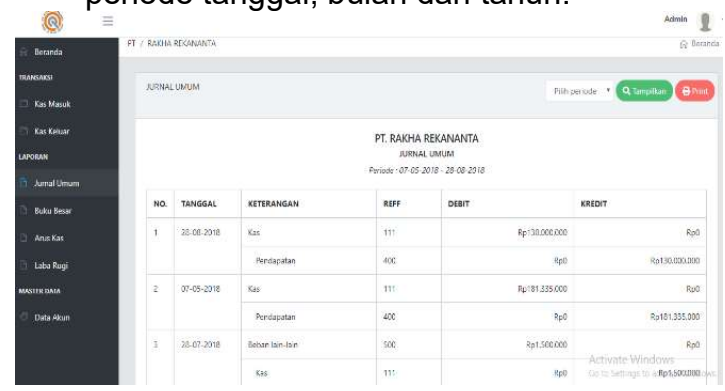


Sumber: Hasil Perancangan (2019)

Gambar 10. User Interface Jurnal Umum

6. User interface buku besar

Pada halaman buku besar ini, admin dapat melihat atau mengakses buku besar dari setiap rekening akun.

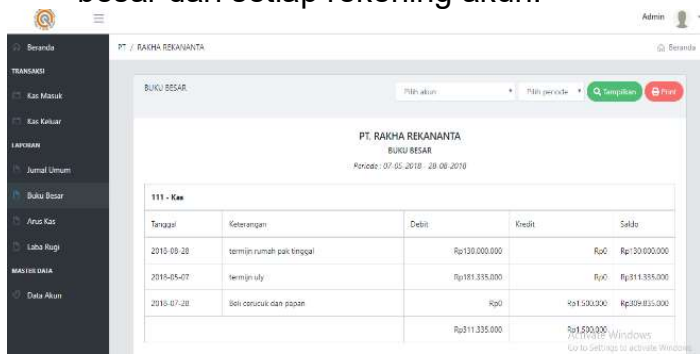

Sumber: Hasil Perancangan (2019)

Gambar 21. User Interface Buku Besar

7. User interface arus kas

Pada halaman laporan arus kas, admin dapat melihat atau mengakses laporan arus kas sesuai dengan periode tanggal, bulan dan tahun.

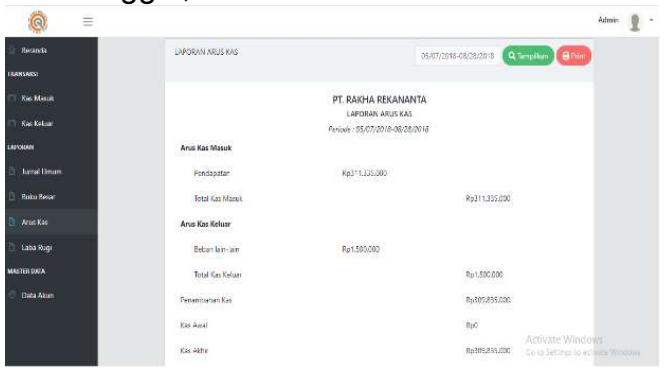

Sumber: Hasil Perancangan (2019)

Gambar 22. User Interface Arus Kas

8. User interface laba rugi

Pada halaman laporan laba rugi, admin dapat melihat atau mengakses laporan laba rugi sesuai dengan periode tanggal, bulan dan tahun.

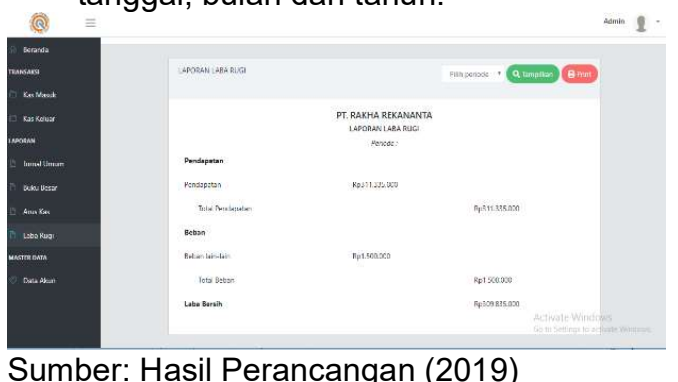

Gambar 23. User Interface Laba Rugi

\subsubsection{User Interface bagian Direktur}

Fasilitas yang didapat oleh Direktur dari sistem informasi kas masuk dan kas keluar PT. Rakha Rekananta Pontianak ini terdiri dari pengolahan data pengguna atau user login, mengakses laporan jurnal umum, mengakses laporan buku besar, mengakses laporan arus kas, mengakses laporan laba rugi. Berikut ini adalah hasil tampilan antar muka atau user interface yang disediakan untuk level pengguna direktur.

1. User interface dashboard Direktur Halaman dashboard direktur ini dapat diakses apabila Direktur telah melewati proses login. Pada halaman dashboard admin ini menyediakan pengolahan data pengguna atau user login, mengakses laporan jurnal umum, mengakses buku besar, mengakses laporan arus kas, mengakses laporan laba rugi, mengakses tambah pengguna dan logout.

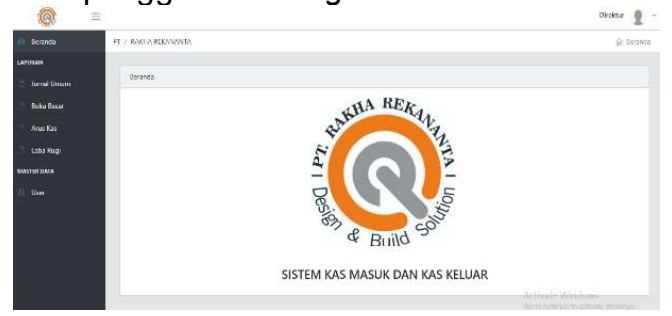

Sumber : Hasil Perancangan (2019)

Gambar 24. User Interface Dashboard Direktur

2. User interface jurnal umum

Pada halaman laporan jurnal umum, direktur dapat melihat atau mengakses laporan jurnal umum sesuai dengan periode tanggal, bulan dan tahun.

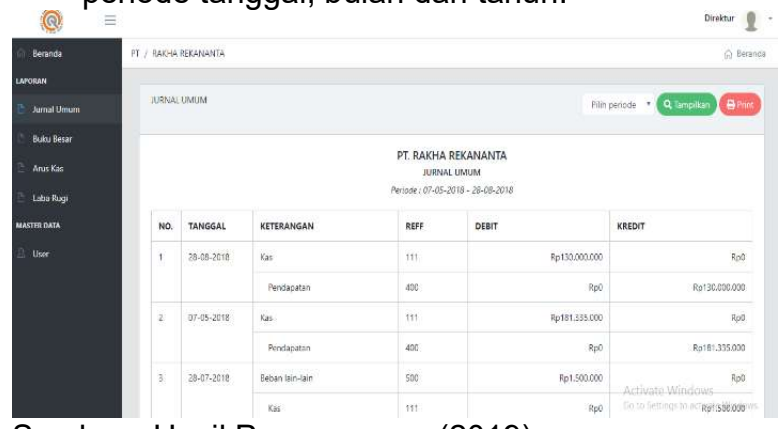

Sumber : Hasil Perancangan (2019)

Gambar 26. User Interface Jurnal Umum

4. User interface buku besar

Pada halaman buku besar ini, direktur dapat melihat atau mengakses buku besar dari setiap rekening akun. 


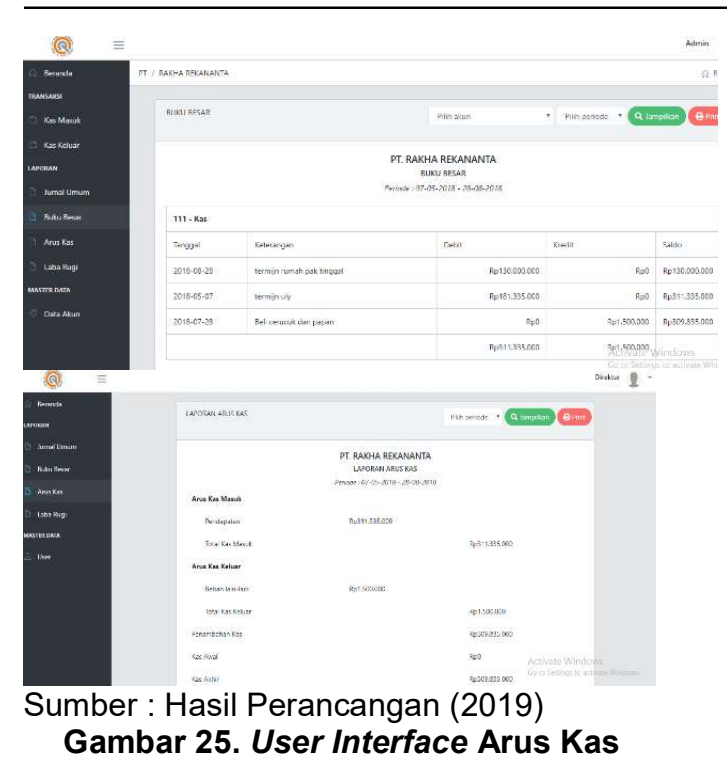

3. User interface laba rugi Pada halaman laporan laba rugi, direktur dapat melihat atau mengakses laporan laba rugi sesuai dengan periode tanggal, bulan dan tahun.

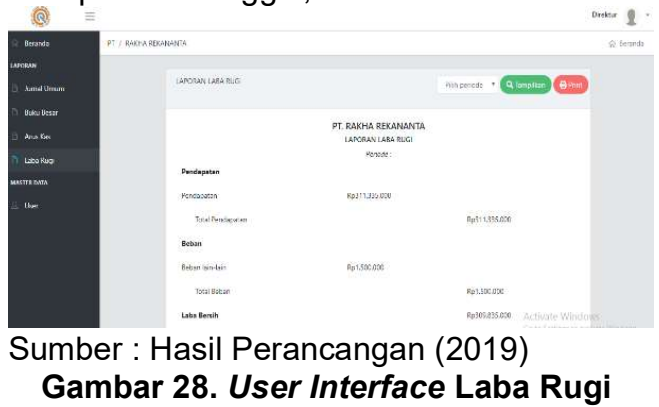

6. User interface tambah user Pada halaman ini, direktur dapat mengelola data user login mulai dari penambahan, pengubahan dan penghapusan data pengguna atau user login.

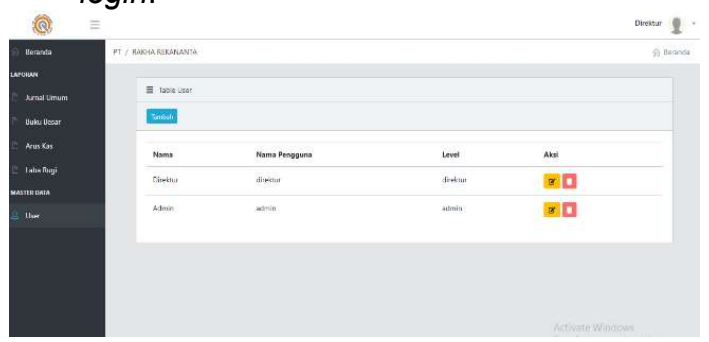

Sumber : Hasil Perancangan (2019)

Gambar III. 29 User Interface Tambah Use4.

\section{Kesimpulan}

4. Dari hasil penelitian yang diperoleh, akurasi dari penggunaan algoritma klasifikasi K-Nearest Neighbor dalam
Sumber : Hasil Perancangan (2019)

Gambar 27. User Interface Buku Besar

5. User interface arus kas

Pada halaman laporan arus kas, direktur dapat melihat atau mengakses laporan arus kas sesuai dengan periode tanggal, bulan dan tahun.

prediksi Bank Marketing sebesar $74,37 \%$ dengan nilai $K=9$, Kesimpulan

Berdasarkan hasil pembahasan yang telah diuraikan pada bab sebelumnya mengenai sistem informasi kas masuk dan kas keluar pada PT. Rakha Rekananta Pontianak, dapat disimpulkan bahwa:

1. Sistem yang dibuat ini menyediakan pengolahan kas masuk dan kas keluar yang dilengkapi dengan laporan keuangan.

2. Sistem yang dibangun ini menyediakan fasilitas sesuai dengan level aksesnya. Level akses pada sistem ini terdiri dari admin dan direktur. Admin dapat melakukan mengelola data akun, mengolah kas masuk dan kas keluar, mengelola laporan jurnal umum, buku besar, arus kas, laba rugi. Direktur dapat mengelola data pengguna atau user login dan dapat mengakses laporan jurnal umum, buku besar, arus kas, laba rugi.

3. Sistem informasi kas masuk dan kas keluar ini diharapkan dapat membantu pihak PT. Rakha Rekananta Pontianak.

Untuk kedepannya aplikasi kas masuk dan kas keluar ini dapat dikembangkan lebih kompeleks dengan penambahan fitur-fitur seperti back-up dan restore data agar keamanan data lebih terjaga, serta penambahan untuk bisa mengelola data transaksi lainnya.

\section{Referensi}

Assronjani, Z. Z. ibnu A., Firliana, R., \& Sari, K. R. T. P. (2019). Sistem Informasi Penjualan Daging Sapi Berbasis Web. Seminar Nasiona Inovasi Teknologi UN PGRI, 134-137. Retrieved from http://semnasinotek.ft.unpkediri.ac.id/o is/index.php/semnasinotek/article/view /171/149.

Abdullah, F., \& Siswanti, T. (2019). PERSEDIAAN TERHADAP PROFITABILITAS ( Study Empiris Perusahaan Manufaktur Sektor Makanan dan Minuman Yang 
Terdaftar di BEI Periode 2014-2017). 4(1). Retrieved from http://journal.universitassuryadarma.a c.id/index.php/jbau/article/view/259/23 4

Fajarianto, O., Iqbal, M., \& Cahya, J. T. (2017). Sistem Penunjang Keputusan Seleksi Penerimaan Karyawan Dengan Metode Weighted Product. Sisfotek Global, 7(1), 49-55.

Jayanti, D., \& Iriani, S. (2014). Sistem Informasi Penggajian Pada CV . Blumbang Sejati Pacitan. Sistem Informasi Penggajian, 6(3), 36-43. http://ijns.org/journal/index.php/speed/ article/view/1041

Putri, G. M., Nangoi, G., \& Alexander, S. (2018). Analisis Sistem Dan Prosedur Pengadaan Kas Dan Pembayaran Dana Pensiun Pada PT. POS Indonesia Manado. Jurnal Riset Akuntansi Going Concern, 13(2), 486495. Retrieved from https://ejournal.unsrat.ac.id/index.php/ gc/article/view/19664/19249
Mara Destiningrum, Q. J. A. (2017). Sistem Informasi Penjadwalan Dokter Berbassis Web Dengan Menggunakan Framework Codeigniter (Studi Kasus: Rumah Sakit Yukum Medical Centre). Teknoinfo, 11(2), 6-13. Retrieved from http://ejurnal.teknokrat.ac.id/index.php /teknoinfo/article/view/24

Suryati, E. V. I. (2018). Sistem Pengeluaran Kas Pada Kantor Sekretariat Dprd Kabupaten Bengkalis. Menara IImu, 12(80), 42-49. Retrieved from https://www.jurnal.umsb.ac.id/index.ph $\mathrm{p} / \mathrm{menarailmu} /$ article/viewFile/642/575

Taruna, K., \& Kas, A. (2018). Jurnal teknik informatika. 6(2). Retrieved from http://jurnal.stmik-

dci.ac.id/index.php/jutekin/article/view/ 340

Jaya, H. (2018). (Akuntansi, Ekonomi, Universitas Riau Kepulauan, Indonesia). Measurement, 12(2), 33-48. Retrieved from https://www.journal.unrika.ac.id/index.php/ measurement/article/view/1741/1285. 